\title{
BOX-PCR is an adequate tool for typing of clinical Pseudomonas aeruginosa isolates
}

\author{
Katarzyna Wolska ${ }^{1}$, Barbara Kot ${ }^{1}$, Antoni Jakubczak ${ }^{2}$, Katarzyna Rymuza ${ }^{3}$ \\ ${ }^{1}$ Department of Microbiology, University of Natural Sciences and Humanities in Siedlce, Poland \\ ${ }^{2}$ Food Technology Institute, State College of Computer Science and Business Administration \\ in Lomza, Poland \\ ${ }^{3}$ Department of Experimentation, Crop Breeding and Seed Science, University of Natural Sciences \\ and Humanities in Siedlce, Poland
}

\begin{abstract}
In this study, the BOX-PCR fingerprinting technique was evaluated for the discrimination of clinical Pseudomonas aeruginosa isolates. All isolates were typeable and nearly half showed unique banding patterns. According to our results, BOX-PCR fingerprinting is applicable for typing of Pseudomonas aeruginosa isolates and can be considered a useful complementary tool for epidemiological studies of members of this genus. (Folia Histochemica et Cytobiologica 2011; Vol. 49, No. 4, pp. 734-738)
\end{abstract}

Key words: Pseudomonas aeruginosa, bacterial diversity, DNA typing method, BOX-PCR

\section{Introduction}

Pseudomonas aeruginosa is an organism commonly occurring in soil, water, plants, animals and humans. Normally, Pseudomonas aeruginosa resides in the intestinal tract of a rather small percentage of healthy individuals. It is found sporadically in moist areas of the human skin and in the saliva. It can multiply in almost any moist environment and has minimal nutritional requirements. Moreover, it is tolerant to a wide variety of physical conditions. Consequently, the microorganism can be found frequently in the hospital environment and home reservoirs such as sinks, floors, baths, soapdishes and dishcloths. Pseudomonas aeruginosa is considered an opportunistic pathogen as it causes hospital-acquired infection, particularly in immunocompromised hosts, burn victims or in those with faulty homeostasis mechanisms or metabolic disorders [1-3].

Correspondence address: K. Wolska, Department of Microbiology, University of Natural Science and Humanities in Siedlce, Prusa Str. 12, 08-110 Siedlce, Poland;

tel.: (+ 48 25) 64313 40;

e-mail:kwolska@uph.edu.pl
Pseudomonas aeruginosa can be internally divided into subgroups by classical methods such as biotyping, serotyping, pyocin typing and phage typing. However, the discriminatory power is much lower than that obtained by molecular typing methods. DNA typing methods have been frequently used for investigating the diversity of collections of Pseudomonas aeruginosa [4]. These methods include pulsed-field gel electrophoresis (PFGE) [5, 6], ribotyping [7], restriction fragment length polymorphic DNA analysis (RFLP) [7], random amplified polymorphic DNA assay (RAPD) [3, 5], arbitrary primed PCR (AP-PCR) [3], amplified fragment length polymorphism (AFLP) [5], and repetitive element based PCR (rep-PCR) [3, 6, 7].

Rep-PCR is a method for fingerprinting bacterial genomes, which examines strain-specific patterns obtained from PCR amplification of repetitive DNA elements present within bacterial genomes. Three main sets of repetitive elements are used for typing purposes: the repetitive extragenic palindromic (REP) sequence, the enterobacterial repetitive intergenic consensus sequence (ERIC) and the BOX elements. REP-PCR and ERIC-PCR have been shown to be useful for typing Pseudomonas aeruginosa isolates [8]. 
To our knowledge, the rep-PCR fingerprinting method using the BOX primer has never been tested on Pseudomonas aeruginosa in Poland.

In this work, we used the BOX-PCR method for the typing of clinical Pseudomonas aeruginosa isolates.

\section{Material and methods}

Bacterial strains. Sixty two strains of Pseudomonas aeruginosa were originally isolated from a variety of clinical specimens: feces (26); urine (12); blood (1); bronchial washings (8); sputum (1); wound swab (9); throat swab (2; ulceration swab (1); swab from skin around tracheotomy (1); and from ear (1). The bacteria were obtained from 62 patients from different wards of the Municipal Hospital, Main Hospital and the outpatients' department in Siedlce (Poland), between December 2005 and March 2006. The strains were identified as Pseudomonas aeruginosa according to biochemical patterns in the Api 20NE system (bio Mérieux). The control strain NCTC 6749 was also examined. Stock cultures were stored in TSB (tripticase soy broth, Difco) containing $20 \%$ glycerol at $-80^{\circ} \mathrm{C}$.

DNA extraction. Isolates were grown in TSB at $37^{\circ} \mathrm{C}$ for $24 \mathrm{~h}$ and DNA was extracted using the Genomic DNA Pre Plus (A\&A Biotechnology, Gdansk, Poland).

BOX-PCR typing. BOX-PCR fingerprinting was carried out using one primer of sequence 5'-CTACGGCAAGGCGACGCTGACG-3'. Amplification was carried out with a $10 \times$ PCR buffer (100 mM Tris-HCl, $1 \mathrm{mM}$ DTT, $0.1 \mathrm{mM}$ EDTA, $100 \mathrm{mM} \mathrm{KCl,} \mathrm{0.5 \%} \mathrm{Nonidet} \mathrm{P40,} \mathrm{0.5 \%} \mathrm{Tween} \mathrm{20)}$ in a total reaction of $50 \mu \mathrm{l}$ containing $2.5 \mathrm{mM}$ dNTP, $20 \mathrm{mM}$ $\mathrm{MgCl}_{2}, 100 \mathrm{pmol}$ of primer, $2 \mu \mathrm{l}$ of genomic template DNA, and 1 unit of Taq DNA polymerase (DNA Gdansk, Poland). BOX-PCR typing was carried out according to Dawson et al. [7] using a PTC-100 Programmable Thermo Controller (MJ Research) according to the following procedure: initial denaturation at $94^{\circ} \mathrm{C}$ for $5 \mathrm{~min}$ followed by 35 cycles of PCR consisting of denaturation at $94^{\circ} \mathrm{C}$ for $1 \mathrm{~min}$, annealing at $48^{\circ} \mathrm{C}$ for $2 \mathrm{~min}$, and extension at $72^{\circ} \mathrm{C}$ for $2 \mathrm{~min}$; in the last cycle, the extension time was $5 \mathrm{~min}$. The PCR product $(10 \mu \mathrm{l})$ was analyzed using a $2 \%$ agarose gel in the TBE buffer (5.4 $\mathrm{g} \mathrm{l}^{-1}$ Tris, $2.75 \mathrm{~g} \mathrm{l}^{-1}$ Boric acid, $0.37 \mathrm{~g} \mathrm{l}^{-1}$ EDTA $(\mathrm{pH} 8.0)$ ) and photographed under a UV light. The size of the products was analyzed using a M100-1000 bp ladder MW size marker (DNA Gdansk, Poland).

\section{Results and discussion}

Various molecular techniques have been developed for typing strains of Pseudomonas aeruginosa [3, 5-7]. Pulse field gel electrophoresis (PFGE) is recognized as the gold standard typing method for Pseudomonas aeruginosa. However, it is labor intensive and limited by high cost and extended turnaround time [5, 6, 8]. In contrast to PFGE, the highly specific rep-PCR technique is an easy procedure, requiring little time for results, and is characterized by low labor costs [6-8]. Rep-PCR with primers based on REP and ERIC sequences has been successfully used to differentiate strains of Bartonella spp., Bacillus subtilis, Citrobacter diversus, Enterobacter aerogenes, Salmonella enterica Typhi, methicillin-resistant Staphylococcus aureus, Streptococcus pneumoniae, Acinetobacter baumanii, Burkholderia cepacia, Burkholderia pseudomallei, Pseudomonas aeruginosa, Legionella pneumophilia, Helicobacter pylori, Neisseria gonorrhoeae and Neisseria meningitidis. While REP and ERIC sequences are the most commonly used targets for DNA typing, another repetitive element, the BOX sequence, has been used to differentiate Streptococcus pneumoniae [8]. Recently, the BOX-PCR method was used for typing strains of different genera of Pseudomonas (Pseudomonas aeruginosa, Pseudomonas syringae, Pseudomonas putida and Pseudomonas fluorescens) [6, 7, 9-11].

In the present study, the BOX primer sequence was used in PCR to detect differences in the number and distribution of this bacterial repetitive sequence in the clinical isolates Pseudomonas aeruginosa genomes. BOX-PCR fingerprinting revealed 38 genetic patterns, among them seven main genotypes, containing three to eight isolates and 30 other unique patterns. The clusters were shown in two to 11 bands between $280-1,550$ bp. More than half of the isolates had five to eight bands per pattern. The most characteristic products of PCR for Pseudomonas aeruginosa were the following: 200, 420, 650, 1,200 and 1,400 bp (Figure 1).

Two of the genotypes ( 8 and 21) consisted of seven $(11.3 \%)$ and eight $(12.9 \%)$ isolates, respectively. The next two most numerous genotypes (4 and 13) contained four $(6.45 \%)$ isolates. All these isolates were obtained from the feces of patients hospitalized in the Main and Municipal Hospitals. Because the incidence of the same genetic types of Pseudomonas aeruginosa isolated from feces occurred in two different hospitals, it was possible to postulate that the same clone was present in the environments of both hospitals. The remaining three numerous genotypes (11, 23 and 5), respectively, consisted of isolates from wound (3 isolates), bronchial washings (3), urine (2), and wound (1) patients being treated at the Main Hospital. Other unique types were collected from the following clinical specimens: urine $(83.3 \%)$, wound (55.5\%), bronchial washings $(62.5 \%)$, feces $(11.5 \%)$ and sputum (1), throat swab (2), ulceration swab (1), swab from skin around tracheotomy (1), blood (1) and from ear (1). This data demonstrated that isolates from 

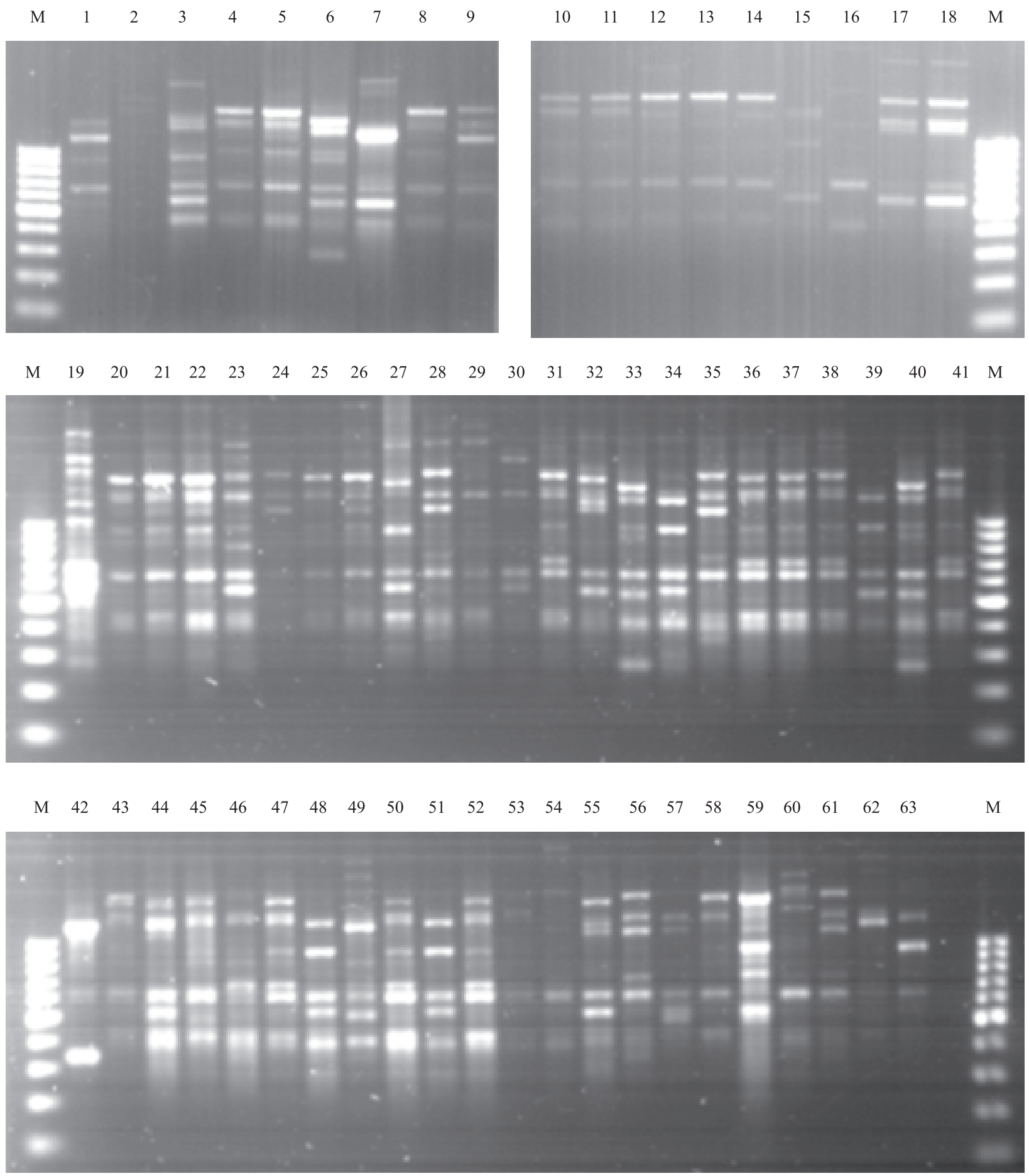

Figure 1. BOX-PCR fingerprinting of Pseudomonas aeruginosa strains. The lane $\mathrm{M}$ is a molecular weight marker (MW100-1000 bp, DNA-Gdansk, Poland)

urine, wound and bronchial washings were highly heterogeneous; among 12, nine and eight isolates, 11 , seven and six respectively different clusters appeared, while the group of isolates from feces showed slight genetic variations. In the group of 26 isolates, we detected seven genotypes (Table 1).

Similar results were obtained using the ERIC-PCR method for typing the same Pseudomonas aeruginosa isolates; 11 major clonal groups and 25 unique genotypes [12]. This result is in agreement with the studies of Syrmis et al. [6], in which the ERIC-PCR and BOX-PCR methods have the same discriminatory power. These authors showed six major clonal groups, and 58 distinct clonal groups among 163 Pseudomonas aeruginosa strains isolated from patients with cystic fibrosis. Morrelli et al. [11] by the BOX-PCR meth- 
Table 1. Compilation of BOX-PCR data for clinical Pseudomonas aeruginosa isolates

\begin{tabular}{|c|c|c|c|c|c|c|c|}
\hline $\begin{array}{l}\text { No. of } \\
\text { isolates }\end{array}$ & $\begin{array}{l}\text { BOX-PCR } \\
\text { genotype }\end{array}$ & $\begin{array}{c}\text { Source } \\
\text { of isolation }\end{array}$ & $\begin{array}{c}\text { Hospital/ } \\
\text { /ward* }\end{array}$ & $\begin{array}{l}\text { No. of } \\
\text { isolates }\end{array}$ & $\begin{array}{c}\text { BOX-PCR } \\
\text { genotype }\end{array}$ & $\begin{array}{c}\text { Source } \\
\text { of isolation }\end{array}$ & $\begin{array}{c}\text { Hospital/ } \\
\text { /ward* }\end{array}$ \\
\hline 1 & 1 & Urine & Main/1 & 33 & 5 & Urine & Main/6 \\
\hline 2 & 2 & Urine & Main/2 & 34 & 23 & Bronchial washings & Main/5 \\
\hline 3 & 3 & Wound & Main/3 & 35 & 24 & Bronchial washings & Main/7 \\
\hline 4 & 4 & Feces & Municipal/4 & 36 & 21 & Feces & Municipal/4 \\
\hline 5 & 4 & Feces & Municipal/4 & 37 & 21 & Feces & Main/8 \\
\hline 6 & 5 & Urine & Main/5 & 38 & 21 & Feces & Municipal/4 \\
\hline 7 & 6 & Urine & Main/6 & 39 & 25 & Bronchial washings & Main/10 \\
\hline 8 & 4 & Feces & Municipal/4 & 40 & 5 & Wound & Main/3 \\
\hline 9 & 7 & Sputum & Main/7 & 41 & 21 & Feces & Municipal/4 \\
\hline 10 & 8 & Feces & Main/8 & 42 & 26 & Throat swab & Main/7 \\
\hline 11 & 8 & Feces & Municipal/4 & 43 & 8 & Feces & Main/8 \\
\hline 12 & 4 & Feces & Main/8 & 44 & 27 & Urine & $\begin{array}{l}\text { Outpatients' } \\
\text { department }\end{array}$ \\
\hline 13 & 8 & Feces & Municipal/4 & 45 & 8 & Feces & Municipal/4 \\
\hline 14 & 8 & Feces & Municipal/4 & 46 & 28 & Wound & Main/9 \\
\hline 15 & 9 & NCTC6749 & - & 47 & 21 & Feces & Municipal/4 \\
\hline 16 & 10 & Wound & Municipal/9 & 48 & 23 & Bronchial washings & Main/10 \\
\hline 17 & 11 & Wound & Main/3 & 49 & 29 & Urine & Main/11 \\
\hline 18 & 11 & Wound & Main/2 & 50 & 21 & Feces & Municipal/4 \\
\hline 19 & 12 & $\begin{array}{l}\text { Bronchial } \\
\text { washings }\end{array}$ & Main/7 & 51 & 23 & Bronchial washings & Main/10 \\
\hline 20 & 13 & Feces & Municipal/4 & 52 & 21 & Feces & Municipal/4 \\
\hline 21 & 13 & Feces & Municipal/4 & 53 & 30 & Feces & Main/8 \\
\hline 22 & 13 & Feces & Municipal/4 & 54 & 31 & Ulceration & Municipal/9 \\
\hline 23 & 14 & Throat swab & Main/7 & 55 & 11 & Wound & Main/2 \\
\hline 24 & 15 & Skin & Main/7 & 56 & 32 & Bronchial washings & Main/7 \\
\hline 25 & 13 & Feces & Main/8 & 57 & 33 & Urine & Main/8 \\
\hline 26 & 16 & Feces & Main/8 & 58 & 8 & Feces & Main/8 \\
\hline 27 & 17 & Wound & Main/2 & 59 & 34 & Feces & Main/8 \\
\hline 28 & 18 & $\begin{array}{l}\text { Bronchial } \\
\text { washings }\end{array}$ & Main/7 & 60 & 35 & Blood & Main/12 \\
\hline 29 & 19 & Wound & Main/9 & 61 & 36 & Bronchial washings & Main/7 \\
\hline 30 & 20 & Urine & $\begin{array}{l}\text { Outpatients' } \\
\text { department }\end{array}$ & 62 & 37 & Urine & $\begin{array}{l}\text { Outpatients' } \\
\text { department }\end{array}$ \\
\hline 31 & 21 & Feces & Municipal/4 & 63 & 38 & Ear & $\begin{array}{l}\text { Outpatients' } \\
\text { department }\end{array}$ \\
\hline 32 & 22 & Urine & $\begin{array}{l}\text { Outpatients' } \\
\text { department }\end{array}$ & & & & \\
\hline
\end{tabular}

1. Obstetric-gynecological ward; 2. Orthopedic trauma ward; 3. Orthopedic ward; 4. Infectious ward; 5. Urological ward; 6. Rehabilitation ward;

7. Intensive care unit (ICU); 8. Pediatric ward; 9. Surgical ward; 10. Neurological ward; 11. Pathology of pregnancy ward; 12. Oncology ward

od found 179 genotypes in 340 Pseudomonas aeruginosa isolates from CF patients. Liu et al. [3], using the ERIC-PCR method, indicated that the 47 isolates of Pseudomonas aeruginosa that had caused bactere- mia in 19 cancer patients were indistinguishable. 17 other isolates that had caused bacteremia in ten cancer patients were discriminated into eight further groups. The 24 environmental and non-cancer patient 
isolates were grouped into further distinct groups. In contrast, Dawson et al. [7] demonstrated the considerable homogeneity of Pseudomonas aeruginosa isolates and, conversely, the heterogeneity within the other species, in particular Pseudomonas putida and Pseudomonas fluorescens.

The results of this study demonstrated that BOX-PCR is a rapid and highly discriminatory and reproducible assay which proved to be a powerful surveillance tool for typing Pseudomonas aeruginosa isolates.

\section{References}

1. Hauser AR, Sriram P. Severe Pseudomonas aeruginosa infections. Tackling the conundrum of drug resistance. Postgrad Med. 2005;117:41-48.

2. Hoiby N, Pedersen SS, Shand GH, Dőring G, Holder IA. Pseudomonas aeruginosa infection. Chemother Basel Karger. 1989;42:124-129.

3. Liu Y, Davin-Regli A, Bosi C, Charrel RN, Bollet C. Epidemiological investigation of Pseudomonas aeruginosa nosocomial bacteraemia isolates by PCR-based DNA fingerprinting analysis. J Med Microbiol. 1996;45:369-365.

4. Speert DP. Molecular epidemiology of Pseudomonas aeruginosa. Front Biosci. 2002;1:354-361.

5. Speijer H, Savelkoul PHM, Bonten MJ, Stobberingh EE, Tjhie JHT. Application of different genotyping methods for
Pseudomonas aeruginosa in a setting of endemicity in an intensive care unit. J Clin Microbiol. 1999;37:3654-3661.

6. Syrmis MW, $\mathrm{O}^{\prime}$ Carrol MR, Sloots TP et al. Rapid genotyping of Pseudomonas aeruginosa isolates harboured by adult and paediatric patients with cystic fibrosis using repetitive-elementbased PCR assays. J Med Microbiol. 2004;53:1089-1096.

7. Dawson SL, Fry JC, Dancer BN. A comparative evaluation of five typing techniques for determining the diversity of fluorescent pseudomonads. J Microbiol Meth. 2002;50:9-22.

8. Olive MD, Bean P. Principles and applications of methods for DNA-based typing of microbial organisms. J Clin Microbiol. 1999;37:1661-1669.

9. Currie BJ, Gal D, Mayo M et al. Using BOX-PCR to exclude a clonal outbreak of melioidosis. BMC Infect Dis. 2007;7:68-71.

10. Marques ASA, Marchaison A, Gardan L, Samson R. BOX-PCR-based identification of bacterial species belonging to Pseudomonas syringae - P. viridiflava group. Genet $\mathrm{Mol}$ Biol. 2008;31:1415-1422.

11. Morelli P, Melioli G, Mentasti M et al. Molecular epidemiology of Pseudomonas aerations from Italian cystic fibrosis patients. European Society of Clinical Microbiology and Infectious Diseases, Barcelona, Spain, 19-22 April 2008, abstract number: P1676.

12. Wolska K, Szweda P. A comparative evaluation of PCR ribotyping and ERIC-PCR for determining the diversity of clinical Pseudomonas aeruginosa isolates. Pol J Microbiol. 2008;57:157-163.

Submitted: 14 October, 2010

Accepted after reviews: 1 May, 2011 